\title{
Author Correction: Hibernation induces widespread transcriptional remodeling in metabolic tissues of the grizzly bear
}

\author{
Heiko T. Jansen (1), Shawn Trojahn (1), Michael W. Saxton (1), Corey R. Quackenbush, \\ Brandon D. Evans Hutzenbiler, O. Lynne Nelson, Omar E. Cornejo, Charles T. Robbins \& Joanna L. Kelley (D)
}

Correction to: Communications Biology https://doi.org/10.1038/s42003-019-0574-4, published online 13 September 2019.

In the original published version of the article, the Mapping section of the Methods incorrectly read "Trimmed reads were mapped to the brown bear (Ursus arctos) reference genome assembly (GCF_000687225.1) ${ }^{62}$ using HISAT2 (version 2.1.0) ${ }^{63}$." The correct genome assembly reference for Ursus arctos is GCF_003584765.1 (reference 25). In addition, the following text was added: “we also mapped the reads to the polar bear (Ursus maritimus) reference genome assembly (GCF_000687225.1) ${ }^{62}$ and results were consistent". The error has been corrected in the HTML and PDF versions of the paper.

Published online: 13 May 2020

\footnotetext{
(c) (i) Open Access This article is licensed under a Creative Commons Attribution 4.0 International License, which permits use, sharing, adaptation, distribution and reproduction in any medium or format, as long as you give appropriate credit to the original author(s) and the source, provide a link to the Creative Commons license, and indicate if changes were made. The images or other third party material in this article are included in the article's Creative Commons license, unless indicated otherwise in a credit line to the material. If material is not included in the article's Creative Commons license and your intended use is not permitted by statutory regulation or exceeds the permitted use, you will need to obtain permission directly from the copyright holder. To view a copy of this license, visit http://creativecommons.org/licenses/by/4.0/.
}

(C) The Author(s) 2020 